\title{
Eating meat and climate change: the media blind spot. $A$ study of Spanish and Italian press coverage
}

\author{
Núria Almiron \& Milena Zoppeddu
}

\begin{abstract}
There is strong evidence that a meat and dairy-based diet is a very important contributor to climate change. However, the correlation between the production and consumption of livestock and anthropogenic climate change has received minimal media coverage. The literature for English-speaking countries shows a sort of media blind spot for meat in that the news media barely address, or do not address, the responsibility of individuals' dietary choices with regard to this issue. In this paper, we provide data for press coverage in Southern Europe from a sample of the top 10 Spanish and Italian newspapers for a seven-year period (2006-2013). Data from our samples correlate with the previous literature. However, data also show that there are meaningful differences between both countries and that their alleged Mediterranean dietary cultural background makes no difference in terms of ethical and dietary sensitivity.
\end{abstract}

Keywords: Climate change, livestock production, meat, media framing

\section{Introduction}

The framing of global warming and its anthropogenic causes in the news media is of great importance to the public's understanding of the subject. The media play a key role in shaping opinions and values in democratic societies, and climate change reporting is no exception (McCombs, 2004; Boyce et al., 2009).

For years, the news media's representation of climate change and global warming exhibited an irrational skepticism that has already been abandoned by most of the media (Boykoff \& Boykoff, 2004 and 2007). ${ }^{\mathrm{i}}$ Nevertheless, media coverage of climate change still shows serious shortcomings, especially with respect to reporting one of its principal causes: our habitual consumption of meat. These limitations are so extensive that we suggest that the media suffer from a sort of blind spot for meat; that is to say, the media do not give due regard to one of the main causes of climate change.

Despite numerous scientific studies over the past 10 years that demonstrate that livestock production is one of the principal human activities that cause climate change, "dietary choices are often left out of environmental discussions" (Freeman, 2010, p. 255). In this paper we contribute our findings on media coverage and framing of the impact of eating meat on climate change in Spain and Italy. On the one hand, our findings show that the continental European media studied correlate with, i.e. confirms, the previous literature. On the other hand, our results show that there are also meaningful differences between the two countries and that their alleged Mediterranean 
dietary cultural background makes no difference in terms of ethical and dietary sensitivity. We suggest that the reasons for this media blind spot might be found in the economy, psychology and culture of the two countries.

\section{Food, climate change and ethics}

According to the Food and Agriculture Organization of the United Nations (FAOStat, 2013), in 2011 around 70 billion land animals were slaughtered around the world to become food for human beings. This number does not include the 150 billion aquatic animals captured in oceans or grown in aquaculture facilities for the same purpose.

These figures have risen decade after decade since the mid- $20^{\text {th }}$ century. Although the cultural practice of eating animals is age-old, the continuous increase in the production and consumption of animal protein is global but varies widely from country to country. This wide-spread consumption of meat dates back about 50 years. In 1960, the number of land animals slaughtered for food across the planet was ten times fewer than the current number (FAOStat, 2013), despite the fact that the global population has "only" doubled since then.

As these figures indicate, the global livestock industry looks after billions of animals on a daily basis, managing their feeding, subsistence and waste. These practices have been carried out on a massive scale for 50 years, and the costs have largely been paid by the environment (IPCC, 2007). This industry has been widely studied by reliable organizations that have provided evidence showing the environmental impact of its activities. Some, including the Worldwatch Institute (2004), FAO (2006) and World Bank (2009), even identify it as the principal cause of global warming: "It has become apparent that the human appetite for animal flesh is a driving force behind virtually every major category of environmental damage now threatening the human future" (Worldwatch Institute, 2004, p. 12).

In 2006, the FAO report entitled Livestock's Long Shadow concluded that livestock production is one of the major causes of the world's most pressing environmental problems. According to this report, livestock are responsible for $18 \%$ of human-induced global greenhouse gas emissions, a bigger share than that of transport $(13 \%)$. There is also evidence suggesting that the livestock industry is also the largest source of water pollutants, including animal wastes, antibiotics, hormones, chemicals from tanneries, fertilizers and pesticides used for feed crops, and sediments from eroded pastures. Livestock use $30 \%$ of the land surface area on the planet and $70 \%$ of agricultural land (FAO, 2006).

In 2007, a public health report on food and energy published in The Lancet claimed that "for the world's higher-income populations, greenhouse-gas emissions from meat-eating warrant the same scrutiny as do those from driving and flying" (McMichael et al. 2007, p. 1261).

In 2007, the Intergovernmental Panel on Climate Change indicated that agriculture produced $13.5 \%$ of world anthropogenic greenhouse gas emissions $\left(\mathrm{CO}_{2}\right.$ equivalent), and that forestry, including deforestation, contributed 17.4\% (IPCC, 2007). A large percentage of these contributions are associated with our habit of eating meat, 
mainly due to the clearing of forests for cattle ranching and soybean production for animal feed.

In 2009, World Bank researchers reported that the FAO's 2006 estimates had been low and that livestock and their by-products actually account for at least $51 \%$ of annual worldwide greenhouse emissions (Goodland \& Anhang, 2009).

In 2010, the United Nations Environment Program released a report that included a section on the severe environmental problems caused by animal agriculture. Its conclusions stated that "a substantial reduction of impacts would only be possible with a substantial worldwide diet change, away from animal products" (UNEP, $2010 \mathrm{p}$. 82).

Furthermore, over the past 30 years, more and more activists, governmental and non-governmental organizations and scholars have rejected the right of humans to confine, exploit, shorten the life of, genetically modify, mutilate and in general cause all kinds of systematic physical and psychological pain to billions of non-human animals (e.g., Spiegel, 1996; Eisnitz, 1997; Patterson, 2002; Scully, 2003; Torres, 2007; Francione, 2008; Pachirat, 2013). Amongst these, philosophers have critically addressed the ethics of these practices in the greatest depth (e.g., Singer, 1975; Regan, 1983; DeGrazia, 1996; Regan, 2004; Singer \& Mason, 2006; Singer, 2009a; Gruen, 2011).

In addition to the cruelty inherent in our treatment of animals, the ethical dimension of this issue also includes the consequences to humans, namely global poverty and hunger. According to the FAO (2006), by consuming more human edible protein than they produce, livestock detract more from the total food supply than they provide. This confirms Frances Moore Lappé's statement more than 40 years ago (1971) that raising animals for food is extremely wasteful of land, grain, water, energy, and other resources, and this at a time when millions die annually from hunger and its effects.

Given these numerous reports from credible sources, one would expect intense media coverage of issues related with climate change and diet, but the fact is that there is a virtual black hole when it comes to green news in general. In the US, for instance, environmental coverage in 2009 represented just $1.5 \%$ of news headlines in the mainstream media (PEJ, 2009) and the figure declined to $1.2 \%$ in 2012 (PIEC, 2013). Although a large portion of environmental news is devoted to climate change (Schmidt, Ivanova, and Schafer, 2013), this topic is clearly underreported if we consider its relevance compared to crime and entertainment, which are the most reported issues. ${ }^{\text {ii }}$

\section{How the correlation between climate change and eating meat has been explained by the media: a literature review}

The media framing of global warming has attracted the attention of numerous academic researchers over the last two decades. Some of the most relevant findings have been summarized by Boykoff: first, the mass media constituted and continue to be a vital mediator of the public understanding of climate change; second, the intensity of media 
attention has been and remains very low, with a few peaks at key moments related with major events; and third, and most important, reporting suffered from an important bias during the 1990s, with overrepresentation of the arguments against the anthropogenic causes of climate change (this bias diminished from 2002 on) (2011). However, this "false balance" remains problematic in at least U.S. coverage (Greenberg, Robbins \& Theel, 2013).

Within the extensive body of literature on media coverage of climate change, the correlation between climate change and the human diet is, however, a lesser researched subfield. To date, relevant findings come mainly from only two studies.

The first study (Neff et al., 2008) examined coverage of the food system's contribution to climate change in a sample of 16 top U.S. newspapers from September 2005 to January 2008 and concluded that coverage of the food system's effects on climate change did not adequately represent the increasingly solid evidence for the importance of these effects. In this research, 4,582 climate change articles were identified for the studied period, of which just 2.4\% (109) mentioned food system or agricultural contributions. Of these 109 articles just 13\% mentioned livestock as a food-related contribution to climate change - only $0.48 \%$ of all climate change articles.

The second study that should be mentioned is that of Kiesel on media coverage of the FAO's Livestock's Long Shadow report in British and American newspapers (2010). Kiesel conducted a comparative rhetorical analysis of selected articles from The New York Times and The Guardian/Observer between November 2006 (when the UN report was released to the public) and December 2008. The search of The New York Times yielded only three articles on the topic of the correlation between livestock production and/or animal product consumption and climate change. The Guardian/Observer search yielded six articles on the topic. Kiesel's analysis shows that both sources generally supported the correlation between livestock production and climate change. However, the most noteworthy consistency in both sources was the very cautious and/or voluntary approach suggested to address the problem (2010, p. 252).

These two studies not only draw attention to the weak dissemination of information on the correlation between climate change and food production in the print media, but also stress that the few articles that did mention the food system as a contributing factor in climate change often directed reader attention to relatively less pressing aspects of the issue.

\section{Theoretical framework and methodology}

"Framing" refers to the ways information is presented and, more precisely, to the unavoidable bias introduced by journalists (McQuail, 2010, p. 380). In spite of the difficulties and subjectivity involved in any framing analysis, researchers have increasingly found ways of addressing some of these weaknesses (Entman, 2010). In this paper, framing is understood as the way journalists represent the facts and the value dimensions (or stances and angles) they highlight (Hansen \& Machin, 2013, p. 107). In formulating the questions and objectives of this research, the framing strategies 
proposed by Gitlin were used as a starting point. Namely, these are the use of official sources, the trivialization of the actions of actors who have opposing viewpoints, attention to the mere event and not to the topic in its widest sense, and emphasis on only one of the arguments (1980, p. 112).

This study is based on 138 articles from the top Spanish and Italian press between November 2006 and September 2013. November 2006 was chosen as a start date because it saw the release of Livestock's Long Shadow. As we have shown, from that moment on, several relevant reports on the same topic (the impact of our meat diet on climate change) were published and therefore we consider that a relevant amount of scientific data on this correlation was available to journalists. Spain and Italy were chosen as both belong to the Mediterranean media and political system model (Hallin \& Mancini, 2004) and no research on this topic had been conducted previously on them. Thus, this study adds new significant data to previous climate change research by analyzing countries from a different cultural background (including the so-called Mediterranean dietary culture) and focusing on framing of meat eating for a 7-year period.

The study aimed to describe press coverage of the correlation between Climate Change and Meat eating (CCM) by conducting:

- a content analysis to examine how CCM articles addressing the impact of Meat On Climate change (MONC) were framed.

- a critical discourse analysis to examine coverage at the linguistic level. This analysis was conducted on a subsample of articles including at least some mention of Livestock's Long Shadow (LLS).

\section{Sample}

The newspaper sample included five of the top Spanish newspapers and five of the top Italian newspapers based on print circulation in 2013. The Spanish newspapers studied were (from highest to lowest circulation): El País, El Mundo, La Vanguardia, El Periódico, and $A B C$. The Italian newspapers studied were (from highest to lowest circulation): La Repubblica, Corriere della Sera, La Stampa, Il Resto del Carlino, and Il Sole 24h. These papers together had an estimated 14 million readers in 2013: 9.2 million in Italy and 4.8 million in Spain. (Audipress, 2013; AIMC, 2013).

Articles were collected from Factiva using the search strings "climate change and/or global warming" AND "meat" AND "livestock" AND "FAO" in all text (Spanish: "cambio climático", "calentamiento global", "carne", "ganado", "FAO"; Italian: "cambiamento climatico", "riscaldamento globale", "carne", "bestiame", "FAO"). Additionally, the "Livestock's Long Shadow" ("La larga sombre del ganado") "iii report was also searched for separately. All genres (informative and opinionbased) were searched, as the aim was to capture a global representation of the correlation that the outlets were transmitting. This generated 774 articles (Spain) and 109 articles (Italy) mentioning both sets of CCM variables at the same time (climate change/global warming and meat eating/meat production) in the 7-year period studied. After excluding articles that did not correlate both variables, we then selected the 
articles that specifically addressed the impact of MONC. For MONC article coding, we tabulated any impact on the environment mentioned as coming from "meat" or "livestock". Articles that addressed the impact of eating meat on climate change or global warming were coded as MONC articles whether or not this impact was a central argument in the article. Articles addressing other impacts were discarded. Articles addressing more than one impact were included as long as the MONC impact was amongst them. This generated a sample of 102 articles for Spain and 36 articles for Italy.

\section{Content analysis}

The authors of this paper were the coders that reviewed the articles. Both countries' results were thoroughly checked for inconsistencies by the first author.

The first analytical model used is consistent with the method of content analysis suggested by Krippendorff (2004). In order to code how MONC articles were framed, each of them was analyzed using a coding sheet recording journal name, date of publication, title, authorship, section of publication, length (in words), cited sources (only regarding the studied correlation), relevance (whether the impact was the central topic of the article or just mentioned in more or less depth) and the focus (whether the stress was on meat eating or on livestock). Relevance was decided mainly by the headlined topic or, if ambiguous, by the text (the topic or perspective that received more attention in the text in terms of number of words). With regard to the focus, articles devoting more words to meat eating as a cause were coded under a "Meat" focus; articles not mentioning our habit of eating meat were coded under a "Livestock" focus. When attention was clearly balanced between both issues, a "Livestock and Meat" focus was chosen.

As for the LLS report, our content analysis examined whether the articles that directly or indirectly quoted the report were focused on the MONC topic (or just mentioned it in the text) and whether they included a summary of the report's contents, conclusions and recommendations.

\section{Critical Discourse Analysis}

The analytical model is consistent in this respect with the method of critical discourse analysis (CDA) suggested by Wodak and Meyer (2001) and Van Dijk (2011). CDA is "fundamentally concerned with analysing opaque as well as transparent structural relationships of dominance, discrimination, power and control as manifested in language" (Meyer and Wodak, 2001, p. 2). The theoretical perspective that informs our CDA is non-speciesist (not assigning different values, rights or special consideration to individuals solely on the basis of their species membership). We took as a starting point the consideration that the relationship of dominance humans exert over non-humans is supported by an ideological worldview that is reproduced in media language choices in a way that prevents readers from understanding their crucial role in the relationship between eating meat and climate change.

A subsample was selected to carry out this analysis. Articles with a direct or indirect mention of the LLS report from the MONC sample were selected, and a search 
for these terms on the newspapers' websites was also conducted. This generated 16 articles from the Spanish newspapers and three articles from the Italian. These 19 texts were analyzed in terms of the details of the linguistic choices they feature in order to reveal meaning that is not necessarily obvious on first reading.

\section{Research questions}

The content and discourse analyses were conducted to answer the following three questions:

1. Coverage: what degree of coverage did the impact of MONC receive?

2. Relevance: what degree of importance was assigned to the impact of MONC as a topic?

3. Focus: was the "meat-eating habit" frame always present?

\section{Findings}

\section{Degree of coverage}

\section{Content analysis}

As shown in Table 1, the terms "climate change" and/or "global warming" (CCGW) were mentioned in 18,921 articles in the Spanish sample and in 3,520 articles in the Italian. These figures give us a glimpse of the popularity of these concepts in the press during the period, particularly in Spain. Articles clearly addressing the topic of climate change as central (including at least "climate change" or "global warming" in the headline and first paragraph) numbered 6,911 and 1,001 for Spain and Italy, respectively, for the period. Of these, $11 \%$ included mention of meat and/or livestock in the full text in both countries; of this 11\%, 102 (Spain) and 36 (Italy) were coded as clearly addressing the impact of meat eating/production on climate change/global warming (MONC). Thus, 1.5\% (Spain) and 3.6\% (Italy) of all articles on climate change during the studied period mentioned the impact of our meat-based diet on the environment. 
Table 1: Coverage overview of the correlation between "climate change" and/or "global warming" and "meat" and/or "livestock" in a sample of 10 leading Spanish and Italian newspapers from November 2006 to September 2013

\begin{tabular}{|l|c|c|c|c|}
\hline & \multicolumn{2}{|c|}{ Spain } & \multicolumn{2}{c|}{ Italy } \\
\hline Articles... & $n$ & $\begin{array}{c}\text { \% of } \\
\text { CCGW } \\
\text { articles }\end{array}$ & $\begin{array}{c}\text { CCGW } \\
\text { articles }\end{array}$ \\
\hline $\begin{array}{l}\text { Mentioning climate change and/or global warming } \\
\text { (in full article) }\end{array}$ & 18,921 & - & 3,520 & \\
\hline $\begin{array}{l}\text { Mentioning climate change and/or global warming } \\
\text { (in headline and first paragraph) (CCGW) }\end{array}$ & 6,911 & 100 & 1,001 & 100 \\
\hline $\begin{array}{l}\text { Mentioning climate change and/or global warming } \\
\text { and meat and/or livestock at the same time (in full } \\
\text { article) (CCM) }\end{array}$ & 774 & 11.2 & 109 & 10.9 \\
\hline $\begin{array}{l}\text { Mentioning the impact of meat eating on climate } \\
\text { change (in full article) (MONC) }\end{array}$ & 102 & 1.5 & 36 & 3.6 \\
\hline
\end{tabular}

Figure 1 shows MONC articles by country across the full study period. Annual numbers of MONC articles ranged from two (November 2006) to nine (September 2013). The two countries followed a similar time trend in that both peaked in 2009, although the Italian newspapers produced a much smaller sample.

Figure 1. Number of articles mentioning the impact of meat eating on climate change/global warming (Spain, $n$ 102; Italy, $n$ 36) by year in a sample of the leading 10 Spanish and Italian newspapers from November 2006 to September 2013

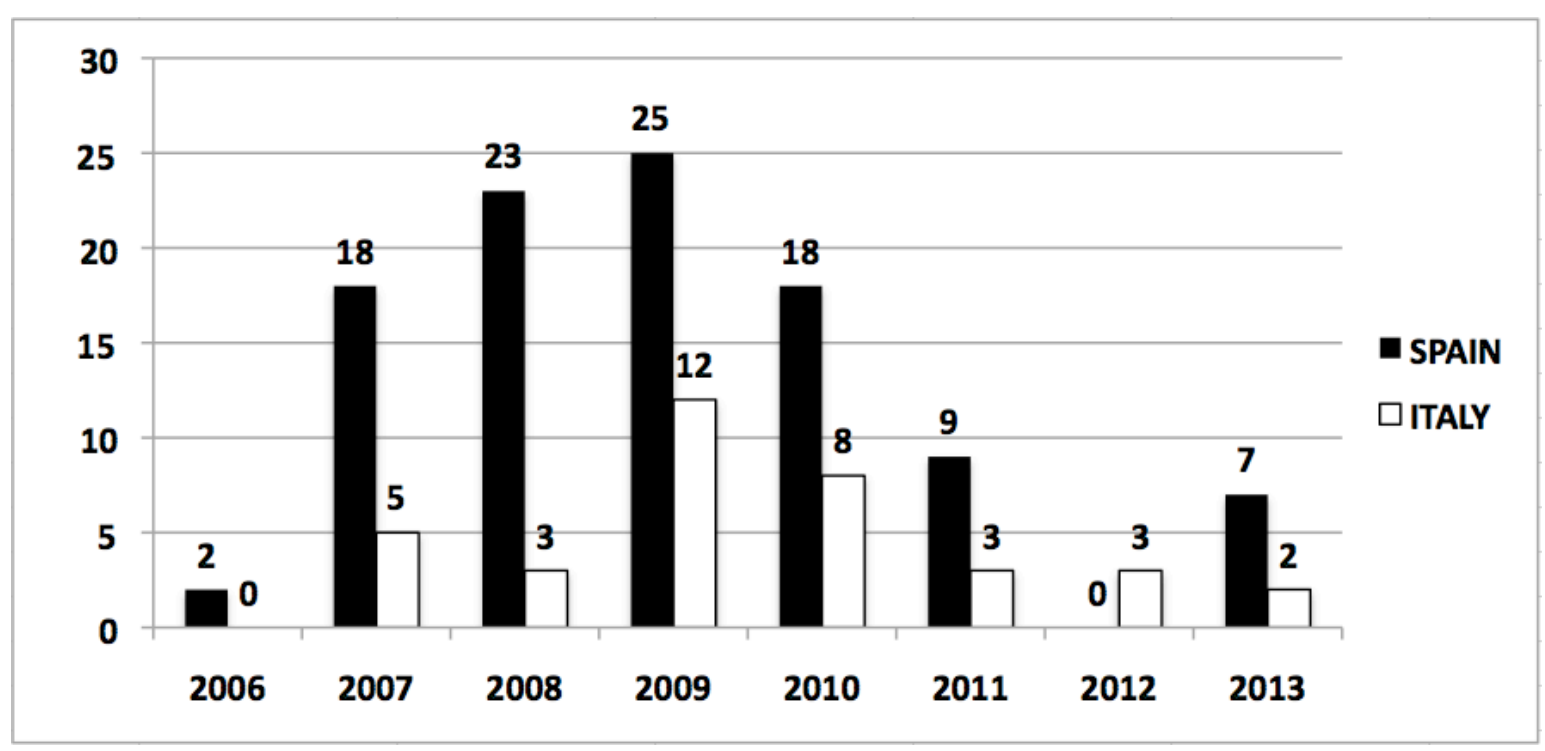


Figure 2. Number of articles mentioning the impact of meat eating on climate change/global warming (S: Spain, $n$ 102; I: Italy, $n$ 36) by newspaper in a sample of the leading 10 Spanish and Italian newspapers from November 2006 to September 2013

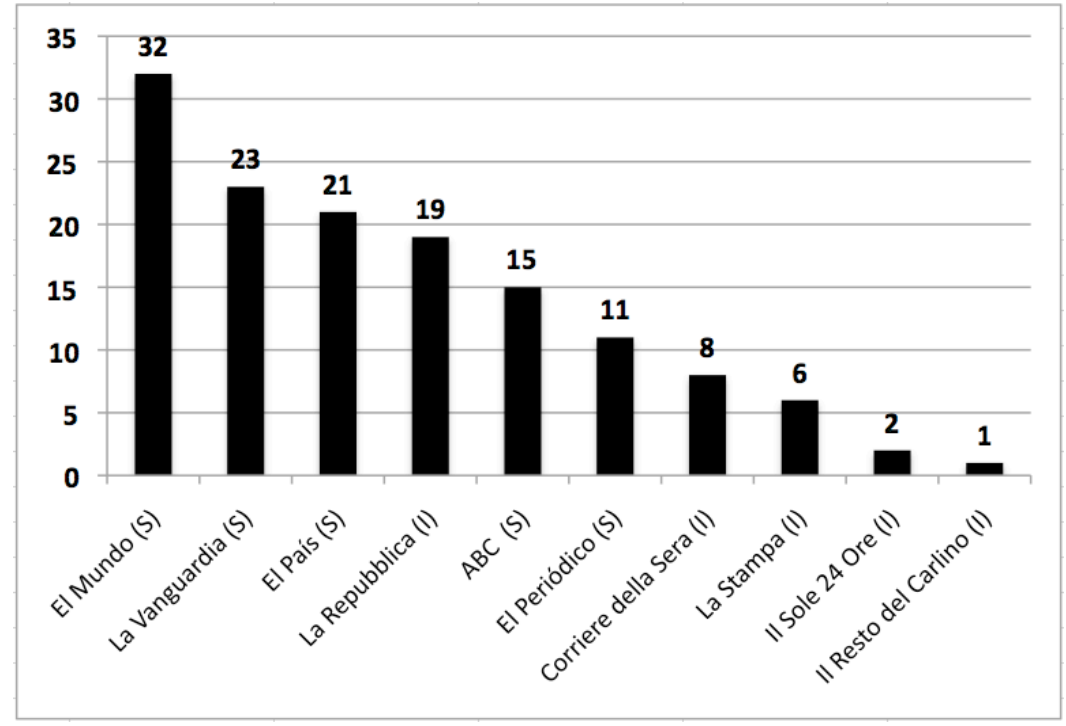

Figure 2 shows MONC articles by newspaper across the full study period. The number of MONC articles ranged from one (Il Resto del Carlino, Italy) to 33 (El Mundo, Spain).

Finally, as Figure 3 shows for both countries, a slight majority of the articles were not focused on the impact of eating meat on climate change but do at least mention it. The percentage of articles that had the MONC issue as the main subject were $39 \%$ (Spain) and $42 \%$ (Italy). Articles that were not focused on the impact of meat on climate change were primarily devoted to the impact of climate change on food.

Figure 3. Percentage of articles mentioning the impact of meat eating on climate change/global warming by central focus in a sample of the leading 10 Spanish and Italian newspapers from November 2006 to September 2013

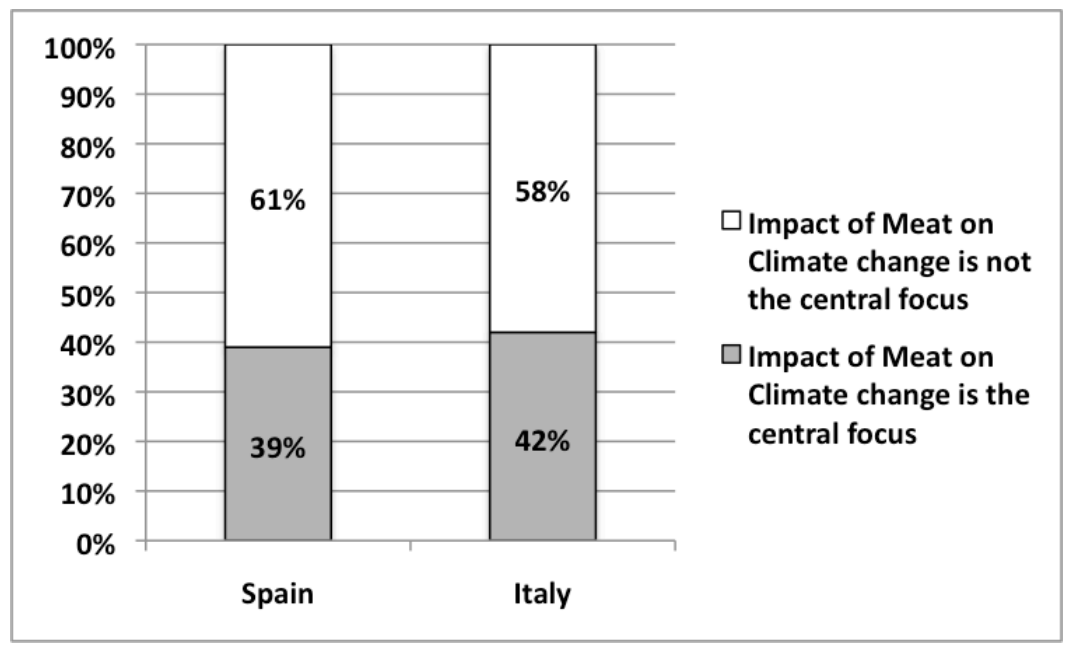


With regard to the FAO, mentions of this UN agency were found in 1,372 (Spain) and 1,423 (Italy) articles for the 7-year period. However, as Table 2 shows, mentions of the LLS report represented less than $2 \%$ of all mentions. Not a single relevant article mentioning LLS was found for El Periódico (Spain).

Table 2: Articles mentioning or covering FAO in a sample of 10 leading Spanish and Italian newspapers from November 2006 to September 2013

\begin{tabular}{|c|c|c|c|c|}
\hline \multirow{2}{*}{ Articles with... } & \multicolumn{2}{|c|}{ Spain } & \multicolumn{2}{|c|}{ Italy } \\
\hline & $n$ & $\%$ of FAO & $n$ & $\%$ of FAO \\
\hline FAO mentions (full text) (FAO) & 1,372 & 100 & 1,423 & 100 \\
\hline $\begin{array}{l}\text { FAO as main topic (headline and first } \\
\text { paragraph) }\end{array}$ & 509 & 37.10 & 623 & 43.78 \\
\hline $\begin{array}{l}\text { "Livestock's Long Shadow" (LLS) report } \\
\text { directly or indirectly mentioned (El Mundo: } 7 \text {; } \\
\text { ABC: } 4 ; \text { El Pais: } 3 ; \text { La Vanguardia: } 2 ; \text { La } \\
\text { Repubblica: } 1 ; \text { Corriere della Sera: } 1 ; \text { La } \\
\text { Stampa: } 1 \text { ) }\end{array}$ & 16 & 1.17 & 3 & 0.2 \\
\hline
\end{tabular}

The percentage of mentions is also under 2\% (Spain: 1.69\%; Italy: $0.3 \%$ ) if we consider articles mentioning the LLS report with respect to all climate change articles published during the period.

Five of the 19 articles analyzed mentioning the LLS report were coded as being focused on the report, eight as including a summary of the report's content in one paragraph, and 16 as mentioning the report's main conclusion: that livestock farming is responsible for $18 \%$ of greenhouse gas emissions. No article was coded as providing a faithful summary of the report's conclusions and recommendations.

\section{Critical discourse analysis}

Textual analyses showed that two articles focusing on the LLS report in the Spanish sample did so in order to undermine its conclusions. El Pais headlined a mistake in its calculations: "La ONU reconoce otro fallo en un estudio sobre el cambio climático" ("The UN recognizes another mistake in a climate change study"). $A B C$ highlighted (first paragraph) the opinion of a livestock specialist criticizing the LLS report: "En contra de la extendida creencia que vincula la reducción de los productos de origen ganadero en nuestra dieta con una gran disminución de las emisiones de gases de efecto invernadero, consumir menor carne y lácteos no tendría un gran impacto en la lucha contra el calentamiento global" ("Contrary to the widespread belief that links the reduction of livestock farming products in our diet with significant reductions in emissions of greenhouse gases, consuming less meat and dairy products would not have a big impact in the fight against global warming"). The lexical choice of "extendida creencia" ("widespread belief") suppresses the fact that empirical evidence supports the study ("belief" is a subjective idea or opinion) and anonymizes the actors that hold such a belief (scientists). 


\section{Degree of Relevance}

\section{Content analysis}

As shown in Figure 4, newspapers from the Spanish sample included MONC articles mainly in the society, trends and culture (27\%), science and environment $(17 \%)$ and opinion (13\%) sections, while the Italian sample placed them mainly in highlighted sections (dossiers, interviews, special reports, front page, etc.) $(36 \%)$.

By outlets, all Spanish newspapers included the majority of their articles in "Society, trends or culture" sections, with the single exception of El Mundo, whose main choice was"Science". Amongst Italian outlets, La Repubblica stands out for publishing up to five pieces on the front page, three of them fully centered on the MONC impact.

Figure 4. Percentage of articles mentioning the impact of meat eating on climate change/global warming by section in a sample of the leading 10 Spanish and Italian newspapers from November 2006 to September 2013

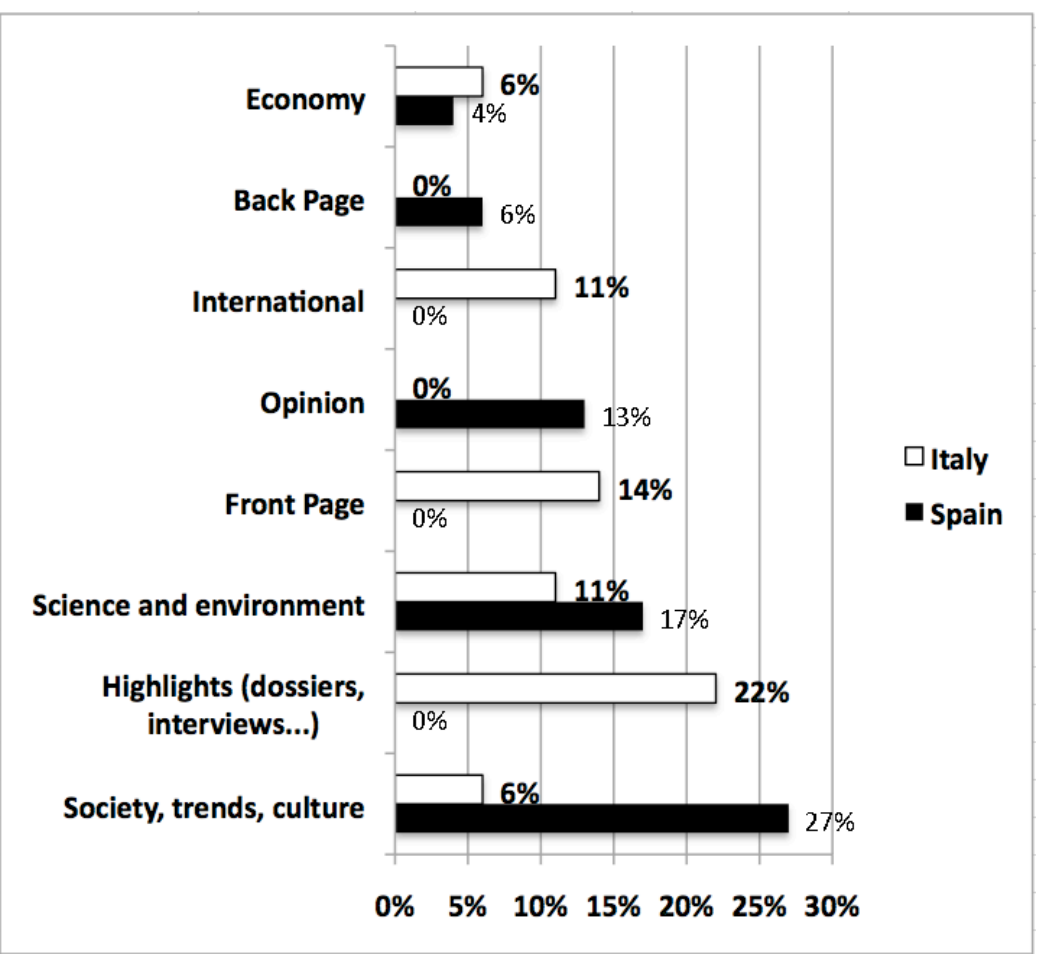

Regarding the sources quoted, we identified up to 51 (Spain) and 36 (Italy) quotations in the articles mentioning the MONC impact. As shown in Table 3, in both countries the FAO is the most quoted source. In the Italian sample, however, individual experts and research institutions not tied to government are almost equally quoted relative to the FAO, while in the Spanish newspapers the Intergovernmental Panel on Climate Change (IPCC) is the second most quoted source. No quotation was found in the Italian outlets referring to the IPCC to provide scientific support for the impact of the human diet on the environment. Thus, articles from the Spanish sample showed a higher tendency to quote official sources (67\% of all sources) than the Italian sample 
(34\% of all sources). However, no mention of either the 2009 World Bank report or the 2010 UNEP were found in any of the Spanish or Italian samples.

Table 3: Sources mentioned to support the impact of meat eating on climate change/global warming in a sample of the leading 10 Spanish and Italian newspapers from November 2006 to September 2013

$\begin{array}{lll}\text { Sources } & \text { Spain }(\boldsymbol{n} \text { 51) } & \text { Italy }(\boldsymbol{n} \text { 36) } \\ \text { FAO } & 31 \% & 26 \% \\ \text { IPCC } & 20 \% & 0 \% \\ \text { Scientists, experts } & 14 \% & 22 \% \\ \text { Research institutions } & 10 \% & 22 \% \\ \text { Other government agencies } & 11 \% & 8 \% \\ \text { NGOs } & 10 \% & 11 \% \\ \text { Activists } & 2 \% & 4 \% \\ \text { Industry sources } & 2 \% & 0 \% \\ \text { Consultancy firms \& Think tanks } & 0 \% & 7 \%\end{array}$

In the Spanish sample, basic content analyses also showed that up to five articles disseminated an erroneous idea from popular culture, that which relates bovine methane emissions to flatulence, when in reality cattle mostly emit methane from their muzzles in the form of eructation, as is clearly indicated in scientific reports.

\section{Critical discourse analysis}

Lexical analysis showed similarities between Spanish and Italian framing of the LLS report. In both samples we found linguistic choices that followed a common pattern: the use of sarcasm. Two of the three Italian articles included personalization and objectivation in their headlines that could have a comic effect for speakers of the language: "La bistecca fa male alla terra" ("Steak harms the planet", La Repubblica) and "Le muche, meno verdi del traffico" ("Cows, the least green traffic", Corriere della Sera). The three Italian pieces, however, avoid any humorous pun in the body of the articles. In contrast, in the Spanish sample, rhetorical tropes with ironic connotations are found in the headlines and body of the text in three newspapers (El País, El Mundo, $A B C$ ). Some, for instance, compare animals with cars: "Las vacas se parecen a los coches más de lo que se cree" ("Cows are more like cars than you think", headline, El País); "Los de los coches no son los únicos tubos de escape que amenazan el planeta" ("Car exhaust pipes aren’t the only ones threatening the planet", El País), "¡Ojo con las vacas!" ("Watch out for the cows!", El País). Others do so with scatological references: "Pedos de vaca" ("Cow farts", Opinion, El Mundo).

Likewise, hyperbole is commonly used in representations of those who support vegetarianism as a way to fight climate change. Spanish $A B C$ referred to the Paul McCartney Meat Free Monday initiative as "La última ocurrencia del ex Beatle" ("The ex-Beatle's latest crazy idea") or "El día elegido para animar al populacho a convertirse en vegetarianos ocasionales" ("The day chosen to convince the mob to become 
occasional vegetarians"). The use of "occurrence" ("crazy idea") and "populacho" ("mob") suggest irrationality and thereby bias readers. This prevents them from having any empathy towards Paul McCartney's vegetarianism and the vegetarian option.

Suppression is another consequence of some lexical choices in the Spanish sample, as we can see in the following two headlines: "Lo más ecológico... ¿que no haya vacas?" ("The greenest thing... No cows?", El País) and "Argentina monta vacas mochileras" ("Argentina assembles backpacker cows", $A B C$ ). In the first example, the question ("No cows?") gives the impression that cows might be the ones to blame since suppressing them might eliminate the problem. The sentence also includes a presupposition: that cows' existence cannot follow a different pattern from the current intensive exploitation they are subjected to (which is the reason for their massive population, digestive problems and, as a result, sizeable gas emissions). In this way, any debate concerning the exploitation of cows is suppressed. In the second example, from $A B C$, the article refers to cows that have undergone an inhumane surgery wherein they have a cannula inserted into their bodies that reaches into the abdominal cavity. The purpose of this surgery is to reduce global warming by capturing bovine gases before they are emitted. The article jokingly refers to them as "vacas mochileras" ("backpacker cows"), which makes light of the cows' situation and hides the painful experience that the animals undergo.

In our sample, only two articles from La Vanguardia (Spain), one of the articles from El Mundo (Spain) and a single article from La Stampa (Italy) avoided the use of lexical choices that make light of the matter either in the headline or in the body of the text.

\section{Focus}

\section{Content analysis}

The MONC topic involves two variables: the habit of meat eating, on the one hand, and livestock farming to obtain a final product for consumption, on the other. We studied whether both variables were considered in all articles, or whether just one of them was stressed. As shown in Figure 5, most of the articles from both samples chose a meat focus, thus stressing, or at least mentioning once, the habit of eating meat as the reason behind livestock's contribution to pollution. 16\% (Spain) and 11\% (Italy) of the articles addressed the issue only focusing on livestock, with no mention of our related dietary choices, and $4 \%$ of the articles from the Spanish sample balanced the focus between both options. 
Figure 5. Percentage of articles mentioning the impact of meat eating on climate change/global warming by focus in a sample of the leading 10 Spanish and Italian newspapers from November 2006 to September 2013

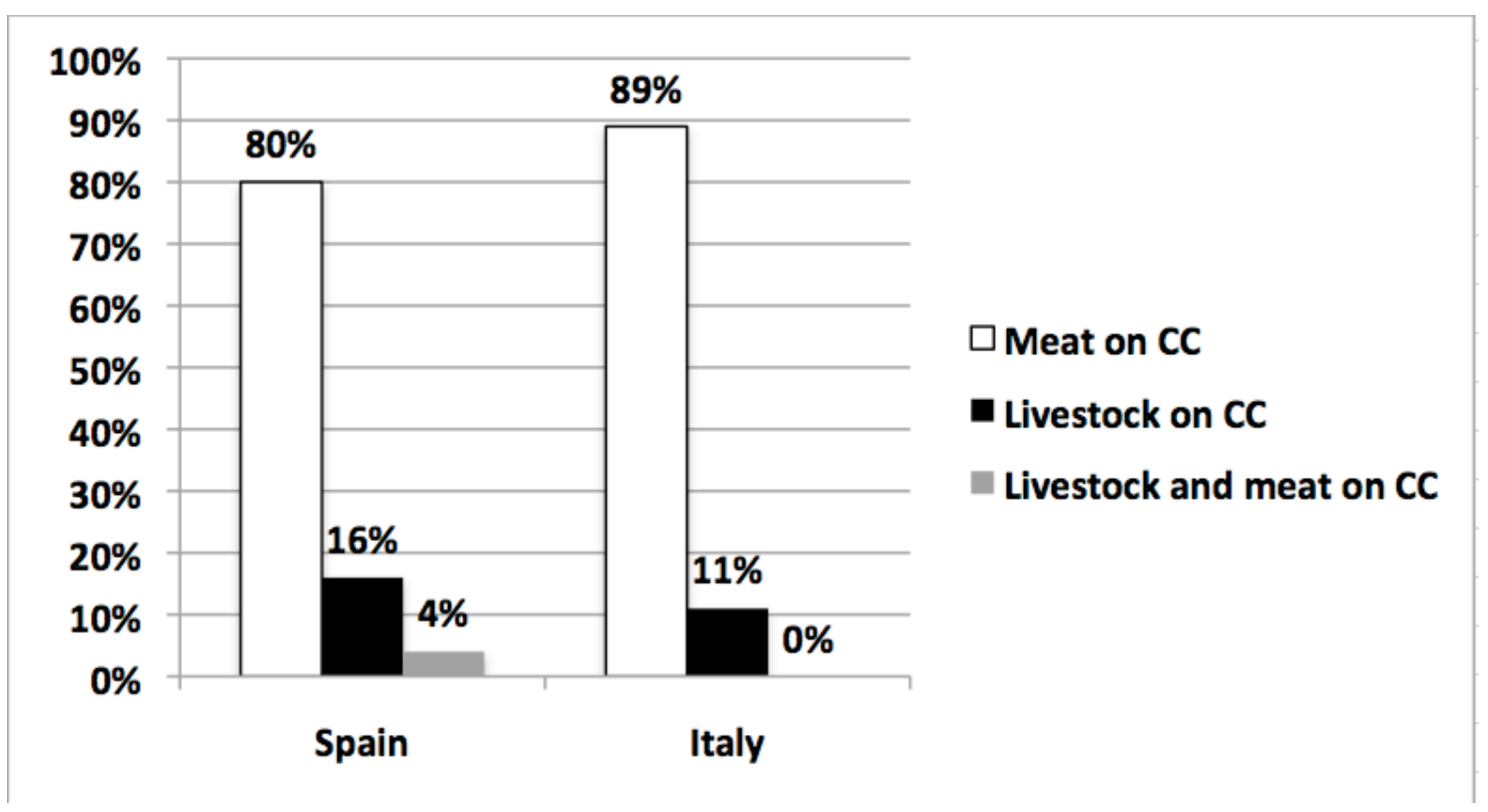

\section{Critical discourse analysis}

Textual analysis shows further differences between newspapers in terms of the linguistic choices used in their reporting of LLS. In the Italian sample, the article from La Stampa was the only one clearly mentioning eating meat as the final problem, which it did by highlighting the reduction of meat consumption as a way to "combattere" ("fight") climate change. In contrast, both La Repubblica and Corriere della Sera articles mentioned technological solutions (such as turning manure into fuel), therefore suggesting that the problem might also, or even mainly, be technological in nature. In La Repubblica article, human dietary choices were mentioned, but in a confusing way: "Se gli attuali trend continueranno, invece, la carne diventerà una minaccia più che un' abitudine" ("If current trends continue, however, meat will become a threat rather than a 'habit"'). Confusion is generated in two ways: (a) the vast majority of scientific studies on the topic state that the meat-eating habit is already a threat to the environment; and (b) the sentence suggests that meat itself, rather than the act of eating meat, is the problem; this can generate the perception of meat being an autonomous variable not dependent on our choices. Confusion also arises from strategic ambiguity (what Wood and Kroger called a "hedging" strategy, 2000) that softens the issue, as is the case of Corriere della Sera in its introductory sentence: "Strano ma vero" ("Strange but true").

In the Spanish sample, more than half (11) of the articles did not address (and thus effectively suppressed) the ultimate cause of the problem (excessive consumption of meat by a minority of the planet's population) and the seven which did address it did so in a way that undermined its importance. Amongst other strategies, this was accomplished again by hedging - choosing words that create a distance that protects the writer from either supporting or opposing an option. The result of this is vagueness, as is reflected in the following headline by El Mundo referring to new taxes created by governments, including a tax on farmers raising methane-emitting cattle: "Los 
gobiernos echan mano de los impuestos más extravagantes" "“Governments resort to the most extravagant taxes"). The reason for the tax on farmers' choices being considered "extravagant" was not clarified in the text, and thus the text takes for granted that taxing farmers for greenhouse emissions is bizarre.

In another article, this time in El Pais, the suggested solutions broke the law of non-contradiction (which states that contradictory statements cannot both be true in the same sense at the same time) while making linguistic choices that could trigger emotion. After reporting in detail on the pernicious effect of livestock farming on the environment, the journalist wrote that "la solución, lógicamente, no es estrangular la ganadería" ("the solution, obviously, is not to strangle the livestock sector") and quoted the following statement by an expert: "Cuando no causa deforestación, 'la ganadería contribuye muy positivamente al mantenimiento del medio ambiente" ("When livestock don't cause deforestation, they make a very positive contribution to the environment"). The paragraph ended with a quote stating that one way to prevent deforestation might therefore be "to promote intensive livestock farming practices". However, intensive livestock farming does not stop animals from eating, which means that deforestation due to crop production does not end; and neither do greenhouse emissions from digestion, nor problems from increasing manure and energy consumption on intensive farms. The result of this logic is confusion, but the "strangle" metaphor may stimulate the reader to agree with the main claim (the solution should in no case involve harming an economic sector), because of the negative emotional connotations of the word "strangle". Another article from El Mundo reported on a scientific study conducted by the Spanish National Research Council (CSIC) to reduce livestock's greenhouse emissions and headlined: "Extractos de ajo y aceites esenciales para reducir los gases de vacas y ovejas" ("Garlic extracts and essential oils to reduce cow and sheep gases"). "Extracts" and essential oils" powerfully recall pleasant treatments, and hence the hard truth behind the news (that humans are trying to modify cows' and sheeps' natural digestion) is softened.

Consumption is clearly presented as the ultimate cause in five texts of the Spanish sample, and the rest of the articles (11) present cattle as the culprit. "¿Cómo puede el ganado hacer tanto daño con su digestión?" ("How can cattle digestion cause so much damage?") stated the journalist in El País, thereby blaming cows and their manure and flatulence, not their fattening due to the enormous demand for their meat. In a later article, however, the newspaper corrects its criminalization of cattle by stating that reducing the consumption of meat in wealthy countries would be a quick and effective method by which citizens could contribute to slowing global warming.

In our examination of the focus in the 19 articles from the LLS sample, we also looked for the deep ethical problem involved in the issue: the massive exploitation of billions of beings. In 17 of the 19 articles the issue was not addressed. The suppression of this ethical dilemma also demonstrates another intratextual presupposition: the assumption that there is no such dilemma, when in fact for many people there is. Two articles, both in Spanish $A B C$, make an exception to this, although to downplay the ethical dilemma. First, the last paragraph of the Meat Free Monday article observes that Paul McCartney's deceased wife was a vegetarian and human rights activist, and that the family is in the business of meat-free food. Second, an article about laboratory hamburgers stated that "la idea de carne sin el coste de las vidas de seres vivos es una 
aspiración que va más allá de las reivindicaciones de los defensores de los animales" ("the idea of meat without the death of living beings is an aspiration that goes beyond the demands of animal advocates"). In the first case, the reader is prompted to conclude that the motivation for Paul McCartney's vegetarian activism does not lie in ethical reasoning but rather in his business interests and/or the personal influence of his first wife (which can also suggest an element of irrationality). In the second case, the writer is suggesting that producing meat in the laboratory has benefits that go beyond animal rights' claims. The journalist made clear what these superior benefits are: stopping livestock from "devastar" ("devastating") the planet. Choosing the word "devastating" places the blame on livestock while suppressing the ethical dilemma and concealing who is actually responsible for it.

Another example of lexical choice that suppresses the ethical dilemma and generates confusion is found in an article from El Pais. In this case the writer asked herself “Ecologistas contra ganaderos?” ("Ecologists against cattle breeders?”). She then stated that "la vaca está en el punto de mira de los ecologistas" ("cows are targeted by environmentalists") because of their gas emissions. She then added that "en defensa de la vaca acude el sector ganadero" ("the livestock sector comes to the defense of cows"). Here, roles are actually reversed: "against" and "targeted" suggest that environmentalists are taking aim at livestock, whereas livestock farmers are presented as those who "defend" the animals.

\section{Discussion}

The current paper has identified a blind spot in the Spanish and Italian press concerning the coverage and framing of the impact of a human habit, eating meat, on climate change.

Our findings correlate with the results of the previous literature studying U.S. and U.K. newspapers. As was the case in the studies carried out by Neff et al. (2008) and Kiesel (2010), our samples yielded low search results: only 1.5\% (Spain) and 3.6\% (Italy) of all articles on climate change during the 7-year studied period mentioned the impact of our meat-based diet on the environment. As did Kiesel's, our discourse analysis on reporting of the LLS report showed that our samples generally supported, with few exceptions, the correlation between eating meat and climate change, while at the same time downplayed the problem and failed to communicate the ethical dilemma behind the issue. Finally, as was the case with Boykoff's findings on global climate change coverage for the US (2011), our findings also show a higher degree of skepticism and "contrarianism" from right-leaning newspapers (mainly Spanish $A B C$ ). From all of this we might conclude that there is no substantial divergence between Southern European and U.S./U.K. coverage, although this should be further contrasted. Does this mean that the alleged different cultural dietary sensibilities of these regions make no difference when addressing a core issue of our diet such as meat? This could be true, though our results also suggest some meaningful Southern European features.

First, there are some disparities between the two countries studied. The Italian newspapers showed much less interest in the MONC topic than the Spanish ones (36 versus 109 articles) but human responsibility was stressed in $89 \%$ of the articles. The Spanish sample, although larger, framed a good percentage of MONC news $(27 \%)$ in 
sections that assigned little relevance to the topic and also showed a higher percentage of articles (20\%) suppressing or downplaying humans' responsibility as meat eaters. The Spanish newspapers also quoted a smaller percentage of independent sources. We suggest, however, that these disparities are not significant due to the fact that both samples failed to represent the overwhelming scientific evidence for the impact of eating meat on climate change.

Second, a disrespectful tone is noteworthy in a substantial portion of the Southern European sample, particularly from Spain. The media in this country showed a very frequent irreverent tone in its coverage that, for instance, was absent in Kiesel's conclusions for the UK and the US. The most radical case was that of the conservative daily $A B C$, a sympathiser of the American Tea Party, that fully fits in the far right stereotype with the highest level of contrarianism challenging the scientific consensus in all of the Southern European sample. However, in the sample from El Pais, the leading newspaper in Spain and a flagship of social democratic ideals, most of the articles featured irony, mistakes or even contrarianism together with facts highlighting the correlation between eating meat and climate change, which had the overall effect of producing a high level of confusion. Newspapers also reflecting social democratic ideals, but usually placed more to the right of the Spanish political spectrum, framed the MONC topic more seriously than El País did in comparative terms - such was the case of El Mundo and La Vanguardia, although both also underreported the issue and El Mundo's sample also included frivolous articles, texts that were superficial and/or reflected a lack of sensitivity.

We suggest three possible reasons for the disparity between Southern European newspaper coverage of the contribution of meat eating to climate change and its coverage of climate change and for the lack of rigor in the issue's framing up to the present point:

Economy. The economic leverage of the agro food industry and its influence on society through advertising and research must be taken into consideration. Spain and Italy are amongst the top meat consumers in the world $\left(10^{\text {th }}\right.$ and $17^{\text {th }}$ in 2009 , respectively, in annual consumption of meat per capita) (FAOStat, 2014). In 2011, consumption of land animal-based food (meat and dairy products) represented $35.6 \%$ of the total food expenditure of families in Spain (Magrama, 2011). Additionally, in Southern European countries, the current economic crisis might also have played a larger role in that massive budget cuts and lay-offs that have reduced the number of experienced journalists in newsrooms. This results in less time and fewer staff to contrast information that is relatively new when the very popular " $\mathrm{CO} 2$ bias" (the trend to emphasize the energy and transportation sectors as the main causes of climate change) is already in place (Neff et al., 2008).

Psychology. Melanie Joy coined the term "carnism" to describe this dominant, yet invisible, paradigm in modern culture that conditions us to eat certain animals. According to Joy, this paradigm is actually a violent ideology that justifies eating meat as "normal, natural and necessary" to "alleviate the moral discomfort we might otherwise feel when eating meat" (2010, p. 96-97). Thus, the ideology of meat eating (carnism) is so culturally ingrained in our psyche that we do not question it. The psychological power held by our age-old tradition of eating meat, which some studies 
suggest is deeply linked with masculinity and virility in Western societies (Adams, 2013), may also play a role. Could machismo help explain why the impact of meat consumption on climate change is lagging behind in the Spanish and Italian media's agenda? It might. Freeman (2010) provided an additional explanation (which is also supported by Neff et al., 2008) for the contradiction of highlighting the problem but not the solution. Freeman showed how environmental advocates have been experiencing the same inconsistency of characterizing the environmental impact of animal products as severe and consumer's responsibility for solving the problem as modest. This cognitive dissonance within the environmental movement may have contributed to the inconsistency of the media coverage in the US and is very likely that the same happened in Europe.

Culture. Freeman (2009, p. 78) also showed that in the US the "news media largely support a speciesist status quo by favoring elite viewpoints and failing to provide balance." In research examining the representations of farmed animals in print and broadcast news, she observed that, with few exceptions, the news media often objectify nonhuman animals discursively through: 1) commodification, 2) a failure to acknowledge their emotional perspectives, and 3) a failure to describe them as individuals with inherent value (p. 78). Our results for Spain and Italy are consistent with this newsroom culture, although further research is needed.

Our research suggests that overall the Spanish and Italian media are underreporting the correlation between climate change and eating meat, and acknowledging the critical role of human dietary habits in it only incidentally and anecdotally. We have identified three different discourse patterns by which media avoid fully addressing this matter: suppression, ambiguity and sarcasm. Suppression makes human responsibility almost invisible, ambiguity prevents the reader from extracting any conclusive meaning from the text, and sarcasm derides the scientific research that draws a connection between meat consumption and climate change. These discourse patterns conceal the environmental and ethical conflict of the so-called ideology of carnism, and in so doing perpetuate the invisibility and dominance of a wider belief system. A belief system that is built on a relationship of power based on extensive violence exerted by the human species over all other species on the planet, on the basis of an alleged moral supremacy of humans. Despite their Mediterranean dietary cultural background, the Spanish and Italian media would thus fit well into this speciesist dominant worldview.

\section{Acknowledgments}

We are most grateful to to the anonymous reviewers of Environmental Communication: A Journal of Nature and Culture and to professor and critical discourse analyst Xavier Giró, from the Universitat Autònoma de Barcelona, whose comments contributed extensively to the improvement of this paper. A first draft only including the Spanish case was presented in the ICA 2013 Conference held in London (United Kingdom) in June, 2013. 


\section{References}

Adams, C. (2013). The sexual politics of meat. A feminist-vegetarian critical theory. New York: Bloomsbury.

AIMC (2013). Resumen general de resultados EGM: Febrero a Noviembre de 2013. Retrieved December 2013 from http://www.aimc.es/-Datos-EGM-ResumenGeneral-.html.

Audipress (2013). Dai cumulati $1^{\circ}$ ciclo 2013 - $2^{\circ}$ ciclo 2013. Audipress. Retrieved December 2013 from http://www.audipress.it/.

Boyce, T. \& Lewis, J. (2009). Climate Change and the Media. New York: Peter Lang. Boykoff, M. (2011). Who speaks for the climate? Making sense of media reporting on climate change. Cambridge: Cambridge University Press.

Boykoff, M.T. \& Boykoff, J.M (2004). Balance as Bias: Global Warming and the U.S. Prestige Press. Global Environmental Change Part A, 14(2), 125-136.

Boykoff, M.T. \& Boykoff, J.M. (2007). Climate change and journalistic norms: A casestudy of U.S. Mass-Media Coverage. Geoforum, 38(6), 1190-1204.

DeGrazia, D. (1996). Taking Animals Seriously: Mental Life and Moral Status. New York: Cambridge University Press.

Eisnitz, G. A. (1997). Slaughterhouse: The Shocking Story of Greed, Neglect, And Inhumane Treatment Inside the U.S. Meat Industry. Amherst, NY: Prometheus Books.

Entman, R.M. (2010) Framing Media Power. In D’Angelo, P. \& Kuypers, J.A. (eds.) Doing News Framing Analysis: Empirical and Theoretical Perspectives (pp.331-55). London: Routledge.

FAO (2006). "Livestock's Long Shadow. Environmental Issues and Options" [Writing Team: Steinfeld, H.; Gerber, P.; Wassenaar, T.; Castel, V.; Rosales, M.; \& de Haan, C.]. Rome: FAO.

FAOStat (2013). FAOStat-Agriculture. Retrieved June 2013 from http://www.faostat.fao.org.

FAOStat (2014). FAOStat-Agriculture. Retrieved February 2014 from http://www.faostat.fao.org.

Francione, G. (2008). Animals As Persons: Essays on the Abolition of Animal Exploitation. Columbia University Press.

Freeman, C.P. (2009). This little Piggy went to press: The American News Media's Construction of Animals in Agriculture". The Communication Review, 12(1), 78-103.

Freeman, C.P. (2010). Meat's Place on the Campaign Menu: how U.S. Environmental Discourse Negotiates Vegetarianism. Environmental Communication: A Journal of Nature and Culture, 4(3), 255-276.

Gitlin, T. (1980). The Whole World Is Watching: mass media in the making and unmaking of the new Left. Berkeley: University of California Press.

Goodland, R. \& Anhang, J. (2009). "Livestock and climate change. What if the key actors are... cows, pigs, and chickens?" World Watch Magazine, 22(6), 10-19.

Greenberg, M.; Robbins, D.; \& Theel, S. (2013). Media Sowed Doubt In Coverage Of UN Climate Report. False Balance And "Pause" Dominated IPCC Coverage. In Media Matters for America, 10th October. Retrieved November 2013 from http://mediamatters.org/research/2013/10/10/study-media-sowed-doubt-incoverage-of-un-clima/196387. 
Gruen, L. (2011). Ethics and Animals. An Introduction. New York: Cambridge University Press.

Hallin, D. \& Mancini, P. (2004). Comparing media systems. Cambridge: Cambridge University Press.

Hansen, A. \& Machin, D. (2013). Media \& Communication Research Methods. New York: Palgrave Macmillan.

IPCC (2007). "Climate Change 2007. Synthesis Report Contribution of Working Groups I, II, and III to the fourth assessment Report of the Intergovernmental Panel on climate Change" [Core Writing Team, Pachauri, R.K., and Reisinger, A. (eds.)]. Geneva: IPCC.

Joy, M. (2010). Why We Love Dogs, Eat Pigs, and Wear Cows: An Introduction to Carnism. San Francisco: Conari Press.

Kiesel, L. (2010). A comparative rhetorical analysis of U.S. and U.K. newspaper coverage of the correlation between livestock production and climate change. In Seitz, E.; Wagner, T.P.; and Lindenfeld, L.: Environmental Communication as a Nexus. Proceedings of the 10th Biennial Conference on Communication and the Environment. Maine: University of Portland, Maine.

Krippendorff, K. (2004). Content analysis (2nd ed.). Thousand Oaks, CA: Sage.

Lappé, F.M. (1971). Diet for a small planet. New York: Ballantine Books.

Magrama (2011). Presentación de los datos de consumo alimentario en España 2011. Ministerio de Agricultura, Alimentación y Medio Ambiente. Spanish Government. Retrieved February 2014 from http://www.magrama.gob.es.

McCombs, M. (2004). Setting the Agenda: the mass media and public opinion, Oxford: Polity.

McMichael, A.J.; Poweles, J.W.; Butler, C.D.; \& Uauy, R. (2007). Food, livestock production, energy, climate change, and health. The Lancet, vol. 370, 55-65.

McQuail, D. (2010). McQuail's mass communication theory (6th ed.). London: Sage

Neff, R.A.; Chan, I.L; \& Smith, K.S. (2008). Yesterday's dinner, today's weather, tomorrow's news? U.S. newspaper coverage of food system contributions to climate change. Public Health Nutrition, 12(87), 1006-1014.

Pachirat, T. (2013). Every Twelve Seconds: Industrialized Slaughter and the Politics of Sight. New Haven, CT: Yale University Press.

Patterson, C. (2002). Ethernal Treblinka. Our treatment of animals and the Holocaust. New York: Lantern Books.

PEJ (2009). Global Warming Generates Little Heat in the Media. Project for Excellence in Journalism. Retrieved in November 2013 from http://www.journalism.org/numbers/global-warming-generates-little-heat-media/

PIEC (2013). Environmental Coverage in the Mainstream News: We Need More. Project for Improved of Environmental Coverage, SEE Innovative. Retrieved November 2013 from http://www.environmentalcoverage.org/ranking

Regan, T. (1983). The Case for Animal Rights. Berkeley: University of California Press

Regan, T. (2004). Empty Cages. Facing the Challenge of Animal Rights. Lanham, Maryland: Rowman and Littlefield.

Schmidt, A.; A. Ivanova; \& M.S. Schafer (2013). Media attention for climate change around the world: A comparative analysis of newspaper coverage in 27 countries. In Global Environmental Change, 23(5), 1233-1248.

Scully, M. (2003). Dominion: The Power of Man, the Suffering of Animals, and the Call to Mercy. New York: St. Martin's Griffin. 
Singer P. \& Mason, J. (2006). The ethics of what we eat. Why our food choices matter. Emmaus, PA: Rodale.

Singer, P. (1975). Animal Liberation: A New Ethics for our Treatment of Animals. New York: Random House.

Singer, P. (2009). Speciesism and Moral Status. Metaphilosophy, 40(3-4), 567-581.

Spiegel, M. (1996). The Dreaded Comparison: Human and Animal Slavery. New York: Mirror Books.

Torres, B. (2007). Making a Killing. The Political Economy of Animal Rights. Oakland, CA: Akpress.

UNEP (2010). Assessing the Environmental Impacts of Production and Consumption:

Priority Products and Materials. A Report of the Working Group on the Environmental Impacts of Products and Materials to the International Panel for Sustainable Resource Management. Hertwich, E., van der Voet, E., Suh, S., Tukker, A., Huijbregts M., Kazmierczyk, P., Lenzen, M., McNeely, J., Moriguchi, Y.

Van Dijk, T. (2011). Discourse Studies. A multidisciplinary introduction. London: Sage. Wodak, R. \& Meyer, M. (2001). Methods of Critical Discourse Analysis, London: Sage Wood, L.A. \& Kroger, R.O. (2000). Doing Discourse Analysis: Methods for Studying Action in Talk and Text. Thousand Oaks: Sage Publications.

Worldwatch Institute (2004). Is meat sustainable? World Watch Magazine, 17(4), 1220.

\footnotetext{
${ }^{\mathrm{i}}$ Not all studies agree with this main hypothesis. Shehata \& Hopmann (2012), for instance, found a total absence of the scientific-uncertainty frame on climate change coverage in the United States in a 10-year comparative study between American and Swedish media.

${ }^{\text {ii }}$ For some news organizations, entertainment and crime garner twenty times and sixty times more coverage, respectively, than the environment, according to the Project for Improved Environmental Coverage. (PIEC, 2013).

iii As no Italian translation of the Livestock's Long Shadow report was available, we looked for the English title.
} 